\title{
HUBUNGAN HARGA DIRI DAN DUKUNGAN SOSIAL TEMAN SEBAYA DENGAN PERILAKU KONSUMTIF PADA SISWI DI SMA NEGERI 1 SUNGGAL
}

\author{
Sariman \\ Email: sariman04@gmail.com \\ Magister Psikologi Universitas Medan Area
}

\begin{abstract}
This study aims to determine the relationship between self-esteem and peer social support with consumptive behavior using quantitative methods. The research was conducted in senior high school 1 Sunggal. The number of respondents in this study were 169 female students of Senior high school 1 Sunggal with purposive sampling sampling technique. The measuring instrument used in this study is the scale of consumptive behavior, self-esteem scale and peer-scale social support. Based on Spearman rank data analysis obtained a significant level between self-esteem and consumptive behavior with a significant value of $0,000<0,05$, meaning that there is a partial relationship between self-esteem and consumptive behavior. While the relationship of peer social support with consumptive behavior with a significant value of $0,000<0,05$. This proves that there is a partial relationship between self-esteem and consumptive behavior. While the significance level of peer social support and self-esteem with consumptive behavior with a significant value of $0,000<0,05$ are related simultaneously, then the hypothesis in this study is accepted. The correlation between self-esteem and peer-to-peer support with consumptive behavior on female students of senior high school 1 Sunggal is $0.500 \%$.
\end{abstract}

Keywords: Consumptive behavior, self-esteem, peer social support.

Abstrak. Penelitian ini bertujuan untuk mengetahui hubungan harga diri dan dukungan sosial teman sebaya dengan perilaku konsumtif dengan menggunakan metode kuantitatif. Penelitian dilaksanakan di SMA Negeri 1 Sunggal. Jumlah responden dalam penelitian ini adalah 169 siswi SMA Negeri 1 Sunggal. Alat ukur yang digunakan dalam penelitian ini adalah skala perilaku konsumtif, skala harga diri dan skala dukungan sosial teman sebaya. Berdasarkan analisis data rank spearman diperoleh taraf signifikan antara harga diri dengan perilaku konsumtif dengan nilai signifikan 0,000 $<0$, 05, artinya membuktikan bahwa terdapat hubungan secara parsial harga diri dengan perilaku konsumtif. Sedangkan hubungan dukungan sosial teman sebaya dengan perilaku konsumtif dengan nilai signifikan $0,000<0,05$. Hal tersebut membuktikan bahwa terdapat hubungan secara parsial harga diri dengan perilaku konsumtif. Sedangkan taraf signifikasi dukungan sosial teman sebaya dan harga diri dengan perilaku konsumtif dengan nilai signifikan $0,000<0,05$ berhubungan secara simultan, maka hipotesis dalam penelitian ini diterima. Besar korelasi hubungan harga diri dan dukungan sosila teman sebaya dengan perilaku konsumtif pada siswi SMA Negeri 1 Sunggal sebesar $0.500 \%$.

Kata Kunci: Perilaku konsumtif, harga diri, dukungan sosial teman sebaya.

10 | Psychophedia Jurnal Psikologi Universitas Buana Perjuangan Karawang 


\section{Pengantar}

Perilaku konsumtif yaitu perilaku berbelanja yang tidak lagi berdasarkan pada pertimbangan yang rasional, melainkan karena adanya keinginan yang sudah mencapai taraf yang sudah tidak rasional lagi (Sumartono, 2002). Dahlan (dalam Yuliantari\& Herdiyanto, 2015) mengatakan bahwa perilaku konsumtif yaitu penggunaan segala hal yang dianggap paling mahal yang memberikan kepuasan dan kenyamanan fisik sebesar-besarnya serta adanya pola hidup yang dikendalikan dan didorong oleh semua keinginan untuk memenuhi hasrat kesenangan semata-mata. Menurut Sumarwan (dalam Andin, 2016) perilaku konsumtif adalah semua kegiatan, tindakan, serta proses psikologis yang terus mendorong seseorang untuk melakukan kegiatan membeli, menggunakan, menghabiskan produk dan jasa yang ada.

Perilaku konsumtif tidak hanya terjadi pada kalangan dewasa, tetapi juga dirasakan oleh kaum remaja. Masa remaja yang merupakan periode transisi kehidupan manusia dari anak-anak menuju dewasa, di dalamnya terdapat proses pencarian jati diri. Hal ini yang menyebabkan seorang remaja mudah untuk ikut atau terimbas hal-hal yang tengah terjadi di sekitarnya (Santrock, 2003). Remaja di sekitar juga terpengaruh oleh trend dan mode yang terjadi, sehingga menjadikan remaja selalu ingin mengikuti arus perkembangan dan gaya hidup yang terjadi saat itu juga.

Menurut Ningsih dan Bawono (2016) para remaja cenderung selalu ingin memiliki barang-barang tersebut dan berlebihan dalam membeli atau mengonsumsi. Sikap atau perilaku remaja yang mengkonsumsi barang secara berlebihan dan tidak wajar inilah yang disebut perilaku konsumtif. Menurut Chrisnawati dan Abdullah (2011) remaja yang memiliki keyakinan bahwa penampilan, terutama pakaian, merupakan sarana yang paling penting dalam penerimaan sosial akan selalu memperhatikan penampilannya. Perilaku konsumtif yang banyak terjadi pada remaja putri pada umumnya hanya sebatas keinginan terhadap barang-barang tersebut dan belum tentu sesuai dengan kebutuhan. Selain itu, remaja putri yang lebih bersifat konsumtif terhadap pakaian dengan merek terkenal.

Pada hasil wawancara yang dilakukan pada ibu T, selaku guru bimbingan konseling di SMA Negeri 1 Sunggal menyatakan bahwa $60 \%$ pelajar gemar untuk melakukan perbelanjaan baik secara langsung maupun secara online. Ibu $\mathrm{T}$ memaparkan bahwa setiap bulan pihak sekolah menerima kiriman dari jasa pengiriman barang yang ditujukan kepada pelajar yang ada di SMA Negeri 1 Sunggal. Ibu T selalu bertanya pada pelajar yang mengenai kiriman yang diterima dan pelajar selalu menjawab bahwa mereka sedang melakukan perbelanjaan online. Tidak hanya itu saja, pelajar perempuan juga kerap dijumpai berada di mallsaat hari libur dengan alasan ini melihat atau membeli produk-produk baru yang ada di mall tersebut seperti tas, baju, sepatu dan lain sebagainya. Menurut ibu $\mathrm{T}$ hal yang wajar jika pelajar menginginkan barang-barang baru, akan tetapi bagaimana cara pelajar dapat membeli barang setiap bulannya jika pelajar belum bekerja. Perilaku ini akan dikhawatirkan jika terus berlangsung pada pelajar nantinya.

Wawancara juga dilakukan pada ibu $\mathrm{R}$ selaku orang tua siswa di SMA Negeri 1 Sunggal. Ibu R menjelaskan bahwa putrinya juga memiliki keinginan yang besar untuk 
memiliki barang-barang baru seperti baju dan sepatu. Di rumah ibu R kerap sekali melihat putrinya sedang melihat pakaian-pakaian baru dari handphone tanpa sadar putrinya mengatakan akan membeli baju ini sesegara mungkin, tetapi ibu $\mathrm{R}$ selalu menolak permintaan putrinya dengan alasan tidak memiliki uang. Menurut ibu $\mathrm{R}$ keinginan anaknya untuk memiliki barang-barang baru terjadi setelah memasuki bangku SMA. Ibu R mengkhawatirkan akan terjadi perilaku negatif pada putrinya jika hal ini terus menerus dilakukan oleh putrinya.

Menurut Wahyudi (dalam Yuliantari \& Herdiyanto) ada empat sifat negatif yang akan terjadi pada remaja jika perilaku konsumtif semakin disukai kalangan remaja, yaitu: 1) Sifat boros, yang hanya menghambur-hamburkan uang dalam arti hanya menuruti keinginan belanja dan keinginan semata. 2) Kesenjangan atau ketimpangan sosial, artinya dikalangan masyarakat terdapat kecemburuan, rasa iri, dan tidak suka di dalam lingkungannya berada. 3) Tindakan kejahatan, artinya seseorang menghalalkan berbagai cara untuk mendapatkan barang yang diinginkannya. 4) Akan memunculkan orang-orang yang tidak produktif, dalam arti tidak dapat menghasilkan uang melainkan hanya memakai dan membelanjakan.

Hasil wawancara bersama AY yaitu siswi SMA Negeri 1 Sunggal mengungkapkan bahwa $90 \%$ wanita di dalam kelasnya mengikuti akun onlineshop yang ada di media sosial. Persaingan untuk memiliki barang-barang branded menjadi motivasi yang besar pada AY. Setiap akhir pekan AY berserta group memiliki rutinitas untuk pergi ke tempat perbelanjaan baju, tas dan sepatu dengan harapan dapat membeli barangbarang terbaru. Selain membeli, AY juga senang melihat barang-barang unik yang
Desember 2019 - Mei 2020

dapat dipakai di sekolah atau di tempat lainnya. Bagi AYpenampilan merupakan cara pelajar manunjukkan jati diri, cara berkomunikasi dan juga menunjukkan pelajar pantas berada dalam suatu kelompok tertentu.

Menurut Fitriani dan Romas (2014) perilaku konsumtif di kalangan remaja mampu meningkatkan angka tingkat kriminal. Tingkat kriminal tersebut sangat beragam, mulai yang ringan seperti pencurian hingga yang berat seperti pembunuhan, narkoba dan prostitusi. Berbagai kasus kriminal tersebut terjadi karena berbagai sebab, namun faktor ekonomi dan pemenuhan kebutuhan lebih mendominasi penyebab terjadinya berbagai kasusu criminal tersebut Battar (dalam Fitriani \& Romas, 2014).

Menurut Sumartono (2002) beberapa faktor yang mempengaruhi perilaku konsumtif yaitu disebabkan oleh dua hal yaitu: Faktor internal, faktor internal yang berpengaruh pada perilaku konsumtif individu adalah motivasi, harga diri, observasi, proses belajar, kepribadian dan konsep diri. Faktor eksternal yang mempengaruhi perilaku konsumtif adalah kebudayaan, kelas sosial, dukungan sosial dari teman sebaya, kelompok-kelompok sosial dan referensi serta keluarga.

Perilaku konsumtif tidak lepas dari harga diri dari masing-masing individu, Menurut Myres (2002) harga diri adalah penilaian diri yang dilakukan oleh seseorang atau individu dan biasanya berkaitan dengan kondisi dirinya sendiri. Penilaian tersebut mencerminkan sikap penerimaan dan penolakan serta penunjukan seberapa jauh individu percaya pada dirinya, mampu, penting, berhasil dan berharga bagi orang lain. Penilaian terhadap diri sendiri sangat 
terkait dengan pengalaman seseorang. Komponen harga diri menurut Felker (dalam Sari, 2009) terdiri dari perasaan diterima (feelingof belonging) yaitu perasaan individu merasa diterima oleh anggota kelompoknya atau teman sebayanya, perasaan mampu (feeling of competence) yaitu individu merasa yakin akan kemampuannya dalam mencapai suatu hasil yang diharapkan, dan perasaan berharga (feeling of worth) yaitu perasaan dimana individu merasa dirinya berharga atau tidak. Komponen perasaan berharga terdapat faktor-faktor dalam komponen ini mencakup sifat pribadi seperti prestasi, penampilan dan mengenai perasaan berharga yang dimiliki oleh individu.

Konsumsi remaja merupakan perilaku pembelian simbolik artinya konsumen membeli sebuah produk semata-mata untuk dipertontonkan pada orang lain (pamer) namun ia tidak tahu fungsi sesungguhnya produk tersebut baik secara fungsional maupun sosial.Semakin tahu remaja atas citra-citra benda yang dibelinya maka semakin mungkin ia berperilaku sesuai dengan citra-citra tersebut (Herlina, 2013). Keyakinan tersebut mempengaruhi tingkat harga diri remaja yang menginginkan untuk diterima oleh lingkungannya terutama oleh teman sebaya sehingga menimbulkan perilaku konsumtif.

Menurut Baron dan Byrne (2004) mendefinisikan harga diri sebagai penilaian terhadap diri sendiri yang dibuat individu dan dipengaruhi oleh karakteristik yang dimiliki orang lain yang menjadi pembanding. Tambunan (dalam Wardhani, 2009) menyatakan harga diri yang positif akan membangkitkan rasa percaya diri, penghargaan diri, rasa yakin akan kemampuan diri, rasa berguna serta yakin kehadirannya diperlukan di dunia ini. Individu yang memiliki harga diri yang rendah akan cenderung merasa bahwa dirinya tidak mampu dan berharga. Menurut Tambunan (2001) harga diri memiliki arti suatu hasil penilaian individu terhadap dirinya yang diungkapkan dalam sikap-sikap yang dapat bersifat positif dan negatif. Bagaimana seseorang menilai tentang dirinya akan mempengaruhi perilaku dalam kehidupannya sehari-hari. Setiap orang memiliki tingkat harga diri yang berbedabeda, yaitu memiliki harga diri yang rendah dan harga diri yang tinggi.

Menurut Gunawan (2003) harga diri merupakan komponen yang bersifat emosional dan merupakan komponen yang sangat penting dalam menentukan sikap dan kepribadian individu. Harga diri didefenisikan sebagai kecenderungan untuk memandang diri sendiri sebagai pribadi yang mampu dan memiliki daya dan upaya dalam menghadapi tantangan-tantangan hidup yang berdasar dan layak untuk bahagia.

Faktor lain yang mempengaruhi perilaku konsumtif adalah dukungan sosial teman sebaya. Menurut Sentrock (2007) teman sebaya adalah merupakan hubungan individu pada anak-anak atau remaja yang memiliki usia atau tingkat kematangan yang kurang lebih sama. Teman sebaya merupakan kumpulan dari beberapa individu untuk memperoleh informasi yang tidak didapat di dalam keluarga, tempat menambah kemampuan dan tempat kedua setelah keluarga yang mengarahkan dirinya menuju perilaku yang baik serta memberikan masukan terhadap kekurangan yang dimilikinya.

Pierre (dalam Andin, 2016) menjelaskan bahwa interaksi teman sebaya adalah hubungan individu pada suatu kelompok kecil dengan ratarata usia yang hampir sama atau sepadan. Masing-masing individu 
mempunyai tingkatan kemampuan yang berbeda-beda. Mereka menggambarkan beberapa cara yanng berbeda untuk memahami satu sama lainnya dengan bertukar pendapat.

Beberapa penelitian terdahulu yang telah meneliti perilaku konsumtif, harga diri dan teman sebaya yaitu: Penelitian yang dilakukan oleh Yuliantari dan Herdiyanto (2015) menemukan hubungan yang signifikan antar harga diri terhadap perilaku konsumtif. Penelitian yang dilakukan oleh Kadeni dan Srijani (2018) bahwa teman sebaya berkontribusi positif terhadap perilaku konsumtif. Chrisnawati dan Abdullah (2011) menemukan hubungan positif teman sebaya terhadap perilaku konsumtif.

\section{Landasan Teori}

\section{Perilaku Konsumtif}

Menurut Tinarbuko (2006) perilaku konsumtif adalah perilaku yang mengutamakan gaya hidup lebih yang bertolak pada felt need saat membeli satu produk yang ditawarkan daripada membeli kebutuhan yang memang diperlukan (real need).Lubis (Sumartono, 2002) mengatakan perilaku konsumtif adalah perilaku yang tidak lagi berdasarkan pada pertimbangan yang rasional, melainkan karena adanya keinginan yang sudah mencapai taraf yang sudah tidak rasional lagi. Menurut Sumartono (2002) perilaku konsumtif dapat diartikan sebagai suatu tindakan memakaiproduk yang tidak tuntas, yaitu belum habis sebuah produk yang dipakai, seseorang telah menggunakan produk jenis yang sama dari merek yang lainnya.

Menurut Lina dan Rosyid (1997) aspek-aspek perilaku konsumtif terdiri dari:

1. Impulsif, yaitu perilaku membeli sematamata karena didasari oleh hasrat yang tiba-tiba atau keinginan sesaat, yang dilakukan tanpa pertimbangan dan biasanya bersifat emosional.

2. Pemborosan, yaitu perilaku menghamburkan banyak dana tanpa didasari adanya kebutuhan yang jelas.

3. Pleasureseeking, perilaku ini berkaitan dengan sifat remaja yang narsistik, ingin mencari kesenangan dengan melakukan pembelian dan keinginan eksis dalam kelompoknya.

4. Satisfactionseeking, perilaku ini didasari oleh adanya keinginan untuk selalu lebih dari yang lain, selalu ada ketidakpuasan dan usaha untuk mendapat pengakuan dari yang lain dan biasanya diikuti rasa bersaing yang tinggi.

Menurut Sumartono (2002) faktorfaktor yang mempengaruhi perilaku konsumtif adalah:

1. Faktor internal, yaitu motivasi, harga diri, observasi, proses belajar, kepribadian dan konsep diri.

2. Faktor eksternal, yaitu kebudayaan, kelas sosial, dukungan sosial teman sebaya, kelompok sosial dan referensi serta keluarga.

\section{Harga Diri}

Menurut Verkuyten (2003) harga diri adalah gagasan mengenai diri secara global yang mengacu pada keseluruhan evaluasi diri sebagai individu, atau bagaimana orang merasakan mengenai diri mereka sendiri dalam arti yang komprehensif. Menurut Baron dan Byrne (2004) mendefinisikan harga diri sebagai penilaian terhadap diri sendiri yang dibuat individu dan dipengaruhi oleh karakteristik yang dimiliki orang lain yang menjadi pembanding.

Sumarwan (2011) menjelaskan bahwa harga diri adalah sikap positif seseorang terhadap dirinya sendiri. Myres (2002) menambahkan bahwa harga diri 
adalah pendapat personal individu tentang nilai dirinya, berdasarkan atas apakah perilakunya telah sesuai dengan ideal diri dan evaluasi seseorang tentang dirinya. Menurut Coopersmith (dalam Lestari\& Koentjoro, 2002) mengatakan bahwa harga diri merupakan hasil evaluasi individu terhadap dirinya sendiri yang diekspresikan dalam sikap terhadap diri sendiri. Evaluasi ini menyatakan suatu sikap penerimaan atau penolakan dan menunjukkan seberapa besar individu percaya bahwa dirinya mampu, berarti, berhasil, berharga menurut standart dan nilai pribadinya.

Reasioner (dalam Nurjanah, 2010) mengungkapkan aspek-aspek harga diri sebagai berikut:

a. Senseofsafe, yaitu perasaan aman yang dirasakan individu dalam bertingkahlaku karena mengetahui apa yang diharapkan orang lain terhadap dirinya, sehingga merasa yakin atas apa yang dilakukannya dan tidakcemas dengan apa yang akan terjadi padanya.

b. Senseofidentity, yaitu kesadaran individu akan potensi, kemampuan dan keberartian dirinya. Sehingga individu merasa dirinya berarti, dicintai dan diterima oleh orang lain juga menyadari potensi dan keunikan yang dimilikinya sekaligus menyadari pula keterbatasannya. Individu dengan senseof identity yang kuat dapat menerima dirinya dan merasa cukup layak untuk menerima pujian.

c. Senseof belonging, yaitu individu merasa dirinya penting dan dibutuhkan oleh orang lain dan merasa dirinya diterima oleh kelompoknya. Individu dengan rasa kepemilikan diri dapat berteman dengan baik, bekerjasama dan perhatian terhadap orang lain. Sehingga individu merasa nyaman.dalam suasana kelompok dan diterima oleh kelompok/teman sebayanya. d. Senseof purpose, keyakinan individu bahwa dirinya akan berhasil mencapai tujuan yang diinginkannya dan merasa memiliki motivasi. Hal ini membuat individu merasa memiliki kekuatan untuk mencapai tujuannya yang realistis dan mampu mengarahkan tingkah laku yang ingin dicapainya, mampu mengambil inisiatif dan melaksanakan tugas-tugasnya. e. Sense of personal competence, yaitu kesadaran individu bahwa dirinya dapat mengatasitantangan dan masalah yang dihadapi dengan kemampuan, usaha serta caranya sendiri. Individu dapat menyadari kelebihan juga menerima kekurangan dirinya. Sehingga individu tidak mudah menyerah dalam menghadapi semua tantangan.

\section{Dukungan Sosial Teman Sebaya}

Dukungan sosial merupakan interaksi interpersonal seperti pemberian perhatian emosi, pemberian bantuan instrumental, penyediaan informasi ataupun pertolongan dalam bentuk lainnya. Hal ini diyakini dapat memberikan kekuatan bagi individu dalam menghadapi efek stress serta memungkinkan untuk meningkatkan kesehatan fisik juga (Taylor, Peplau \& Sears, 2009). Dengan dukungan sosial, individu merasa memperoleh kenyamanan fisik maupun psikologis yang didapat lewat pengetahuan bahwa individu tersebut dicintai, diperhatikan, dihargai oleh orang lain dan juga merupakan anggota dalam suatu kelompok yang berdasarkan kepentingan bersama.

Dukungan sosial didapat dari berbagai macam, seperti dukungan sosial keluarga, dukungan atasan, dukungan teman sekerja dan dukungan teman sebaya. Dalam penelitian ini menfokuskan pada dukungan teman sebaya. 
Aspek-aspek dukungan teman sebaya menurut Cutrona dan Russel (dalam Inayah, 2015) sebagai peneliti pertama dukungan sosial teman sebaya, yaitu:

1. Kelekatan, yaitu kedekatan emosional yang dapat memberikan rasa aman untuk individu.

2. Integrasi sosial, yaitu sebuah rasa tergabung pada kelompok yang sesuai dengan minat, kepedulian dan kegiatan rekreasi yang sama.

3. Adanya pengakuan, yaitu sebagai pengakuan kompetensi, keterampilan dan nilai orang lain.

4. Ketergantungan untuk dapat diandalkan, yaitu keyakinan bahwa orang lain dapat diandalkan untuk dapat membantu secara nyata.

5. Bimbingan, yaitu berupa arahan, masukan dan informasi.

6. Kesempatan untuk merasa dibutuhkan, yaitu perasaan bahwa individu dapat diandalkan untuk kesejahteraan orang lain.

\section{Metode Penelitian}

Penelitian yang digunakan adalah penelitian kuantitatif. Populasi dalam penelitian ini adalah seluruh pelajar yang ada di SMA N. 1 Sunggal. Populasi responden dalam penelitian ini adalah 169 orang. Teknik sampling yang digunakan dalam penelitian ini adalah total sampling dengan mengambil semua populasi menjadi sampel penelitian.

Metode pengumpulan data menggunakan skala perilaku konsumtif, skala harga diri dan skala dukungan sosial teman sebaya.

\section{Hasil Penelitian Dan Pembahasan}

Berdasarkan hasil pengujian hipotesis pada uji korelasi Product moment menggunakan SPSS menunjukan bahwa
Desember 2019 - Mei 2020 pada variabel harga diri (X1) nilai koefisien korelasi (rxy) sebesar 0.519 dan nilai signifikansi $(\mathrm{p})$ sebesar $0.000<0.05$. Hal ini menunjukan bahwa terdapat hubungan secara parsial variabel harga diri (X1) dengan variabel perilaku konsumtif siswi SMA Negeri 1 Sunggal (Y).

Hasil ini menunjukkan bahwa hipotesis pertama yang berbunyi "ada hubungan harga diri dengan perilaku konsumtif siswi SMA Negeri 1 Sunggal", dapat dinyatakan terbukti kebenarannya. Hubungan harga diri (X1) dengan perilaku konsumtif siswi SMA Negeri 1 Sunggal (Y) menunjukkan koefisien korelasi (rxy) sebesar 0.519 yang memiliki arti bahwa kekuatan hubungan harga diri dengan perilaku konsumtif sebesar 51.9\%. Menurut Sumartono (2002) perilaku konsumtif dapat diartikan sebagai suatu tindakan memakaiproduk yang tidak tuntas, yaitu belum habis sebuah produk yang dipakai, seseorang telah menggunakan produk jenis yang sama dari merek yang lainnya.

Menurut Sumartono (2002) perilaku konsumtif dapat diartikan sebagai suatu tindakan memakaiproduk yang tidak tuntas, yaitu belum habis sebuah produk yang dipakai, seseorang telah menggunakan produk jenis yang sama dari merek yang lainnya.

Selain faktor harga diri, perilaku konsumtif juga berhubungan dengan dukungan social teman sebaya. Asumsi tersebut didukung dengan hasil analisis data yang ditunjukkan oleh koefisien korelasi (rxy) dengan nilai signifikansi (p) $0.000<0$, 05 koefisien korelasi (rxy) sebesar 0.544 . Sehingga dapat disimpulkan bahwa ada hubungan dukungan social teman sebaya dengan perilaku konsumtif pada siswa - siswi SMA Negeri 1 Sunggal. Dari hasil penelitian ditemukan Koefisien korelasi (rxy) sebesar 0.544 dan yang memiliki arti bahwa kekuatan 
hubungan dukungan social teman sebaya dengan perilaku konsumtif sebesar 54.4\%.

Menurut Sentrock (2007) teman sebaya adalah merupakan hubungan individu pada anak-anak atau remaja yang memiliki usia atau tingkat kematangan yang kurang lebih sama. Menurut Mappiare (2002) teman sebaya merupakan suatu kelompokyang baru, yang memiliki ciri norma, kebiasaan yang jauh berbeda dengan apa yang ada dalam lingkunan keluarga remaja.

Secara bersamaan hasil penelitian ini menunjukan bahwa ada hubungan antara harga diri dan dukungan social teman sebaya dengan perilaku konsumtif, hal ini didukung dengan hasil analisis data yang ditunjukkan oleh nilai signifikansi (p) sebesar $0.000<$ 0.05. Sedangkan nilai koefisien korelasi (rxy) $=0.500$. Perilaku konsumtif yaitu perilaku berbelanja yang tidak lagi berdasarkan pada pertimbangan yang rasional, melainkan karena adanya keinginan yang sudah mencapai taraf yang sudah tidak rasional lagi (Sumartono, 2002). Dahlan (dalam Yuliantari\& Herdiyanto, 2015) mengatakan bahwa perilaku konsumtif yaitu penggunaan segala hal yang dianggap paling mahal yang memberikan kepuasan dan kenyamanan fisik sebesar-besarnya serta adanya pola hidup yang dikendalikan dan didorong oleh semua keinginan untuk memenuhi hasrat kesenangan semata-mata.

Sesuai dengan hasil penelitian di atas, maka hipotesis penelitian terjawab dengan sempurna yaitu harga diri memiliki hubungan dengan perlikau konsumtif, dukungan sosial teman sebaya memiliki hubungan dengan perilaku konsumtif. Harga diri dan dukungan sosial teman sebaya memiliki hubungan perilaku konsumtif di SMA Negeri 1 Sunggal.

\section{Kesimpulan}

Desember 2019 - Mei 2020

Berdasarkan hasil yang telah diperoleh dalam penelitian ini, maka dapat disimpulkan hal-hal sebagai berikut:

1. Ada hubungan positif yang signifikan antara harga diri dan dengan perilaku konsumtif pada siswi SMA Negeri 1 Sunggal, yang ditunjukkan oleh nilai $\operatorname{signifikansi}(\mathrm{p})=0,000<0,05$ dan arah korelasi (rxy) sebesar 0,519.

2. Ada hubungan positif yang signifikan antara dukungan sosial teman sebaya dengan perilaku konsumtif pada siswi SMA Negeri 1 Sunggal, yang ditunjukkan oleh koefisien nilai signifikansi (p) 0,000 $<0,05$, dan arah korelasi (rxy) sebesar 0,544 .

3. Ada hubungan positif yang signifikan antara harga diri dan dukungan sosial teman sebaya dengan perilaku konsumtif pada siswi SMA Negeri 1 Sunggal, yang ditunjukkan oleh nilai signifikansi (p) $0,000<0,05$. Dengan arah korelasi (rxy) sebesar 0, 5000 .

\section{Kepustakaan}

Al-Mighawar, M. (2006). Psikologi remaja.Bandung: Pustaka Setia.

Andin. (2016). Hubungan interaksi teman sebaya dengan perilaku konsumtif pada siswa kelas XI di SMA N 6 Yogyakarta. E-jurnal Bimbingan dan Konseling, 2, (5), 41-49.

Arikunto, S. (2007). Prosedur penelitian, suatu pendekatanpraktik. Jakarta: Renika Cipta.

Azwar, S. (2009). Reliabilitas dan validitas. Yogyakarta: Sigma Alpha.

Baron, R., \& Byrne, D. (2004). Psikologi sosial jilid 1 (Penerjemah: Djuwita, R.A). Jakarta: Erlangga. 
Chrisnawati, D., Abudullah, S. M. (2011). Faktor-faktor yang mempengaruhi perilaku konsumtif remaja terhadap pakaian. Jurnal Spirits, 2(1), 1-14.

Engel, J.F., Blackwell. \& Miniard. (1995). Consumen Behavior. Jakarta: Binarupa Aksara.

Fitriani \& Romas, M. Z. (2014). Hubungan konsep diri dengan perilaku konsumtif pada remaja di SMK Kesehatan. Jurnal Psikologi, 10, 16-22.

Gunawan, A. W. (2003). Genius learning strategy, petunjuk praktis untuk menerapkan accelerated learning. Jakarta: Gramedia Pustaka.

Herlina, D. (2013). Pemasaran remaja (Studi literatur tentang pemasaran barang dan jasa untuk remaja).

Hidayati, N. K. (2000). Hubungan antara harga diri dan kolektifitas dengan kecenderungan perilaku konsumtif remaja. Tesis (Tidak diterbitkan).

Hurlock, E. B. (1898). Adolencenct development. (Fourt edition). Tokyo: Kosaido Printing.

Inayah, L. (2015). Pengaruh dukungan teman sebaya dan self-efficacy terhadap penyesuaian akademik. Tesis. (Tidak diterbitkan).

Kadeni. \& Srijani, N. (2018). Pengaruh media sosial dan teman sebaya terhadap perilaku konsumtif mahasiswa. Equilibrium, 6(1), 61-70.

Lina. \& Rasyid, H. F. (1997). Perilaku konsumtif berdasarkan locus of control pada remaja putra. Jurnal Psikologika, 4, (1), 69-76.
Desember 2019 - Mei 2020

Mappiera, A. (2002). Psikologi remaja. Surabaya: Usaha Nasional

Notoatmodjo, S. (2003). Metodologi Penelitian Kesehatan. Jakarta: Rineka Cipta.

Ningsih, R. A. A. S., \& Bawono, Y. (2016). Hubungan antara perilaku konsumtif pada produk X dengan citra diri remaja putri. Jurnal Mediapsi, 2, (1), 45-50.

Nurjanah, N. (2010). Efektifitas konseling analisis transaksional untuk meningkatkan self-esteem siswa: Studi kasus terhadap siswa SMAN 1 Cikalongwetan Kabupaten Bandung Barat. Tesis.

Purnomo, S. A. (2006). Hubungan antara konsep diri dengan perilaku kenakalan remaja. Tesis. (Tidak dipublikasi).

Priyatno, D. (2012). Cara kilat belajar analisis data dengan SPSS 20. Yogyakarta: Penerbit Andi.

Santosa, S. (2004). Dinamika kelompok (edisi revisi). Jakarta: Bumi Aksara.

Santrock, J. W. (2003). Adolescence: Perkembanganremaja. Jakarta: Erlangga.

Sari, P. K. P., Indrawati, E. S. (2016). Hubungan antara dukungan sosial teman sebaya dengan resiliensi akademik pada mahasiswa tingkat akhir jurusan $\mathrm{X}$ fakultas teknik universitas Diponegoro. Jurnal Empati, 5,(2), 177-182.

Sari, T. Y. (2009). Hubungan antara perilaku konsumtif dengan body image pada remaja putri.

Sugiyono. (2005). Statistik untuk penelitian. Bandung: Alfabeta.

18 | Psychophedia Jurnal Psikologi Universitas Buana Perjuangan Karawang 
Suhari, Y. (2008). Keputusan membeli secara online dan faktor-faktor yang mempengaruhinya. Jurnal Teknologi Informatika, 2(3), 123-131.

Sumartono. (2002). Terperangkap dalam iklan: Meneropong imbas pesan iklan televisi. Bandung: Alfabeta.

Suseno. \& Sugiyanto. (2010). Pengaruh dukungan sosial dan kepemimpinan transformasional terhadap komitmen organisasi dengan mediator motivasi kerja. Jurnal Psikologi UGM, 1, 94-109.

Tinarbuko, S. (2006). Iklan tontonan masa dan tanggungjawab pelanggaran nilai. Yogyakarta: Kedaulatan Rakyat.

Wahyuni, N. S. (2016). Hubungan dukungan sosial teman sebaya dengankemampuan bersosialisasi pada siswa SMK Negeri 3Medan. Jurnal Diversita, 2(2), 1-11.

Wardhani, M. D. (2009). Hubungan antara konformitas dan harga diri dengan perilaku konsumtif pada remaja putri.

Yuliantari, M. I., \& Herdiyanto, Y. K. (2015). Hubungan konformitas dan harga diri dengan perilaku konsumtif pada remaja putri di kota Denpasar. Jurnal Psikologi Udayana, 2(1), 89-99.

Yusuf, S. (2012). Psikologi perkembangan anak dan remaja.Bandung: Remaja Rosdakarya. 